\title{
Obesity, bariatric surgery and oxidative stress
}

\author{
Roberta Cattaneo Horn ${ }^{1 *}$, Gabriela Tassotti Gelatti ${ }^{2}$, Natacha Cossettin Mori ${ }^{1}$, Ana Caroline Tissiani ${ }^{3}$, \\ Mariana Spanamberg Mayer ${ }^{3}$, Elvio Almeida Pereira ${ }^{4}$, Marcelo Ross $^{5}$, Paulo Ricardo Moreira $^{3}$, \\ Josiane Woutheres Bortolotto ${ }^{1}$, TAMIRIS FELIPPIN ${ }^{2}$ \\ ${ }^{1}$ Professor in the Pharmaceutic Faculty, Universidade de Cruz Alta (Unicruz), Cruz Alta, RS, Brazil \\ ${ }^{2}$ Stricto Sensu Graduate Program in Comprehensive Health Care, Unicruz in association with the Universidade Regional do Noroeste do Rio Grande do Sul (Unijun), Cruz Alta, RS, Brazil \\ 3PhD. Equilibrium Centro Terapêutico da Obesidade, Cruz Alta, RS, Brazil \\ ${ }^{4} \mathrm{Head}$ of the Equilibrium Centro Terapêutico da Obesidade, Cruz Alta, RS, Brazil \\ ${ }^{5}$ Biomedical Faculty, Unicruz, Cruz Alta, RS, Brazil
}

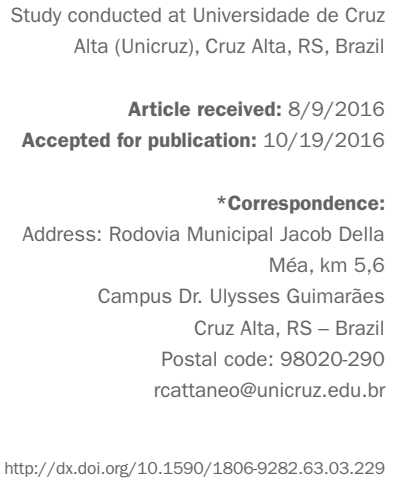

\section{SUMMARY}

Introduction: Obesity refers to the accumulation of fatty tissues and it favors the occurrence of oxidative stress. Alternatives that can contribute to body weight reduction have been investigated in order to reduce the production of reactive oxygen species responsible for tissue damage. The aim of the current study was to assess whether the oxidant and antioxidant markers of obese women before and after bariatric surgery were able to reduce oxidative damage.

Method: We have assessed 16 morbidly obese women five days before and 180 days after the surgery. The control group comprised 16 non-obese women. Levels of thiobarbituric acid-reactive substances, carbonylated proteins, reduced glutathione and ascorbic acid were assessed in the patients' plasma.

Results: Levels of lipid peroxidation and protein carbonylation in the pre-surgical obese women were higher than those of the controls and post-surgical obese women. Levels of reduced glutathione in the pre-surgical obese women were high compared to the controls, and declined after surgery. Levels of ascorbic acid fell in the pre-surgical obese women compared to the control and post-surgical obese women. Conclusion: Body weight influences the production of reactive oxygen species. Bariatric surgery, combined with weight loss and vitamin supplementation, reduces cellular oxidation, thus reducing tissue damage.

Keywords: adipose tissue, reactive species, weight loss, morbid obesity, bariatric surgery, oxidative stress.

\section{INTRODUCTION}

Obesity is defined as excessive body fat accumulation. It is a chronic disease caused by multiple factors, which may seriously harm the health of individuals. The disease has reached epidemic proportions worldwide and results from the interaction of genes, environment, lifestyle and emotional factors. ${ }^{1}$ The prevalence of obesity has rapidly increased in Brazil. The country ranks $5^{\text {th }}$ in the world ranking, amounting to approximately 60 million overweight and 22 million obese individuals. These numbers correspond to $17 \%$ of the population. ${ }^{2}$ Mortality has increased due to comorbidities, since obesity increases the occurrence of several diseases such as hypertension, dyslipidemia, type 2 diabetes mellitus, coronary heart disease, stroke, non-alcoholic fatty liver disease, osteoarthritis, sleep apnea and some types of cancer. ${ }^{3,4}$

Obesity also affects the mitochondrial metabolism, which favors the production of reactive oxygen species (ROS), as well as the development of oxidative stress. ${ }^{5}$ According to the mechanism responsible for ROS occurrence, the intracellular triglycerides inhibit the movement of adenosine nucleotides and lead to adenosine triphosphate (ATP) accumulation, as well as to mitochondrial adenosine diphosphate (ADP) decrease. It reduces the oxidative phosphorylation rate and enables the release of electrons and free radicals, which, in turn, results in the production of reactive species (ROS) that damage tissues and cells. ${ }^{6}$ Thus, dysfunctional tissues or cells trigger an 
inflammatory process that increases the expression of adipokines $(-1,-2$, and -4 monocyte proteins and $-1 \alpha,-1 \beta$, and $-2 \alpha$ macrophage inflammatory protein), leading to macrophage infiltration in the adipose tissue and excessive production of ROS and inflammatory cytokines, which may exacerbate lipid disorders. ${ }^{7}$

Hyperleptinemia is another mechanism that increases the ROS production in obesity. It is found in obese people due to changes in the leptin receptor or due to transport system deficiency in the blood-brain barrier. This phenomenon is called leptin resistance. ${ }^{8}$ Hyperleptinemia induces oxidative stress. It triggers an inflammatory process through mitochondrial increase and peroxisomal fatty acid oxidation. This process stimulates the proliferation and activation of monocytes and macrophages, as well as the production of IL- 6 and TNF- $\alpha .{ }^{9,10}$

Thus, since obesity may pose other health risks, the efficient identification of high body mass index (BMI) is essential to promote health and reduce morbidity and mortality. ${ }^{11}$ In addition to BMI, it is important to quantify cellular, molecular or biochemical markers that indicate tissue or cell changes. It is worth highlighting the markers of oxidative damage caused by the imbalance of fat amount, body weight, lipoproteins and lipids. Such imbalance increases ROS production or affects the activity of the antioxidant system, thus leading to oxidative stress. ${ }^{12}$

Surgery can be an alternative to reduce adipose tissue and, thereby, the damages caused by increased body fat. Roux-en-Y gastric bypass is the most effective procedure and is recommended as the gold standard to treat comorbid conditions related to morbid obesity. ${ }^{5,13}$ Its main benefits to patients are early satiety center stimulation and improvement of the metabolic syndrome cycle with $75 \%$ effective decrease in the initial excess weight. ${ }^{14}$

Vitamin supplementation is essential to prevent nutritional deficiencies resulting from the surgical procedure, as well as to achieve healthy weight reduction. ${ }^{15}$ Ascorbic acid (ASA) stands out as a reducing agent due to the key metabolic role it plays in the human body. It reduces the transition metals (mainly $\mathrm{Fe}^{3+}$ and $\mathrm{Cu}^{2+}$ ) found in active enzyme sites or found in their free forms in the body. Complications such as protein malnutrition, and iron, zinc and vitamin deficiency may occur due to the non supplementation with ASA. ${ }^{16}$

Because of the high number of obesity cases in the population, the increased number of bariatric surgeries, as well as the relation between excess fat tissue and oxidative stress - which may cause health damages - it is imperative knowing the redox state of morbidly obese patients before and after the surgical procedure. Thus, the aim of the current study was to assess the oxidant and antioxidant markers of morbidly obese patients before and after bariatric surgery.

\section{Method}

The current study was approved by the Research Ethics Committee (CEP - Comitê de Ética em Pesquisa) of Cruz Alta University (UNICRUZ - Universidade de Cruz Alta) under protocol number 07720212.0.0000.5322. All participants signed an Informed Consent Form (ICF).

\section{Study participants}

The control group comprised 16 non-obese women with mean BMI $22.1 \pm 0.8 \mathrm{~kg} / \mathrm{m}^{2}$, in the age group 35 to 40 years. They did not smoke, abuse alcohol or had any infectious diseases, or take vitamin supplementation.

The intervention group comprised 16 morbidly obese female patients with BMI $44.1 \pm 6.8 \mathrm{~kg} / \mathrm{m}^{2}$; mean age 37.5 \pm 10.9 years; and mean weight $120.9 \pm 16.6 \mathrm{~kg}$. They did not smoke, abuse alcohol or had any infectious diseases. No vitamin supplementation was reported before surgery. After surgery, the patients received supplementation with multivitamins, according to RDC 269, 2005, adapted for clinical practice, including some antioxidants such as vitamin A (5,000 IU), E (30 IU) and C (60 mg). ${ }^{17}$

These data were provided by an obesity clinic located in Southern Brazil, where these patients were treated.

The participants were evaluated five days before and 180 days after Roux-en-Y gastric bypass. This procedure consists of reducing the gastric capacity to approximately $20 \mathrm{~mL}$ by permanently excluding from the gastrointestinal tract the remaining stomach, as well as the duodenum and the first $50 \mathrm{~cm}$ jejunum. The small gastric pouch is anastomosed to an isolated Roux-en-Y jejunal loop. Its emptying is limited by a silicone ring placed $5.5 \mathrm{~cm}$ distal to the esophagogastric transition and $1.5 \mathrm{~cm}$ proximal to the gastrojejunal anastomosis in order to reduce the gastric lumen diameter to $12 \mathrm{~mm}$. The secretions from the excluded stomach and duodenum flow into the jejunum through a 100 -to- $159 \mathrm{~cm}$ anastomosis located below the gastric pouch; the distance depends on the patient's BMI. ${ }^{18,19}$

\section{Blood collection}

Vacutainer tubes containing ethylenediamine tetraacetic acid (EDTA) were used to collect blood samples five days before and 180 days after bariatric surgery, after 12-hour fasting. The biological material was taken to the Toxicological Analysis Laboratory of Cruz Alta University (Rio Grande do Sul State) and centrifuged at 3,000 rpm for 10 minutes. The plasmas were separated and kept under 
refrigeration at $-20^{\circ} \mathrm{C}$ for further analytical determinations. Hemolyzed or lipemic samples, as well as samples with volume insufficient to allow analytical determinations, were excluded from the study.

\section{Analytical determinations}

The levels of thiobarbituric acid reactive substances (TBARS) were determined according to the methodology described by Jentzsch et al..$^{20}$ This method is based on the malondialdehyde (MDA) reaction to $1 \%$ orthophosphoric acid and to thiobarbituric acid (TBA) at high temperature. The readings were performed at $532 \mathrm{~nm}$ in a visible spectrophotometer and the results were expressed as nmol MDA $/ \mathrm{mL}$.

Carbonylated protein $(\mathrm{CP})$ levels were measured according to the methodology described by Levine et al. ${ }^{21}$ The method consists in dosing CPs through the reaction with $10 \mathrm{mM}$ 2,4-dinitrophenylhydrazine (DNPH), after adding $2 \mathrm{M}$ hydrochloric acid $(\mathrm{HCl})$ and $3 \%$ sodium dodecyl sulfate (SDS) denaturing buffer ( $\mathrm{pH}$ 8.0) to it. The readings were performed at $370 \mathrm{~nm}$ in a visible spectrophotometer and the results were expressed as nmol CPs/mg total protein. Total proteins were measured using the Labtest ${ }^{\circledR}$ kit.

Reduced glutathione (GSH) levels were determined according to the technique described by Ellman. ${ }^{22}$ This technique uses $1 \mathrm{M}$ potassium phosphate buffer (KPB) at $\mathrm{pH} 7.4$ and 5,5'-dithiobis-(2-nitrobenzoic acid) (DTNB). The readings were performed at $412 \mathrm{~nm}$ in a visible spectrophotometer and the results were expressed as $\mu \mathrm{mol} \mathrm{GSH} / \mathrm{mL}$.

Ascorbic acid (ASA) levels were determined using an adapted approach to the methodology by Roe. ${ }^{23}$ The reaction mixture included distilled water, trichloroacetic acid (TCA) and DNPH. The samples were incubated at $37^{\circ} \mathrm{C}$ and, then, the reaction was interrupted for the addition of $65 \%$ sulfuric acid $\left(\mathrm{H}_{2} \mathrm{SO}_{4}\right)$. The readings were performed at $520 \mathrm{~nm}$ in a visible spectrophotometer and the results were expressed as $\mu \mathrm{mol} \mathrm{ASA} / \mathrm{mL}$.

\section{Statistical analysis}

The results were analyzed using Graphpad Prism 5 statistical software and expressed as mean \pm S.E.M (standard error of the mean). The distribution of variables was tested based on Kolmogorov-Smirnov test. The data concerning the same parameters from all the herein studied groups were subjected to one-way analysis of variance (ANOVA) followed by the Tukey-Kramer test for parametric data. The results were considered statistically significant at $\mathrm{p}<0.05$.

\section{Results}

With respect to the oxidative markers assessed in the current study, TBARS (Figure 1) and CP (Figure 2) levels in the pre-surgical obese group were higher than those of the control group and of the post-surgical obese group $(p<0.0001)$. It is worth emphasizing that, according to Figures 1 and 2, the TBARS and CP levels in the post-surgical obese group did not return to the same levels found in the control group ( $\mathrm{p}=0.001)$.

As for the results of the antioxidant markers, the GSH levels (Figure 3 ) of the pre-surgical obese group were higher than those of the control patients $(\mathrm{p}=0.001)$ and of the post-surgical obese group $(p=0.001)$. On the other hand, the ascorbic acid levels (Figure 4) of the obese women before and after the surgery were lower than the ASA levels of the control group ( $\mathrm{p}=0.0001)$.

\section{Discussion}

The presence of excess adipose tissue is indicated as a source of pro-inflammatory cytokines that induce ROS

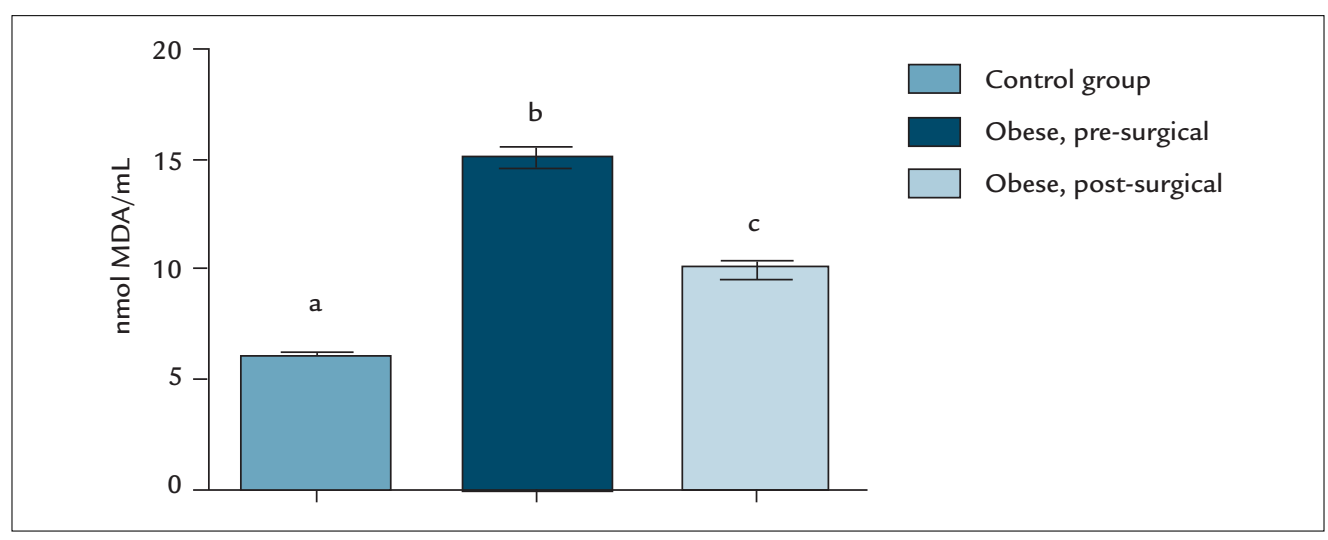

FIGURE 1 Thiobarbituric acid reactive substances levels in the plasma of non-obese women $(n=16)$ and of obese women before and after bariatric surgery $(n=16)$. Different letters indicate significant differences between the studied groups, considering $p<0.05$. MDA: malondialdehyde. 


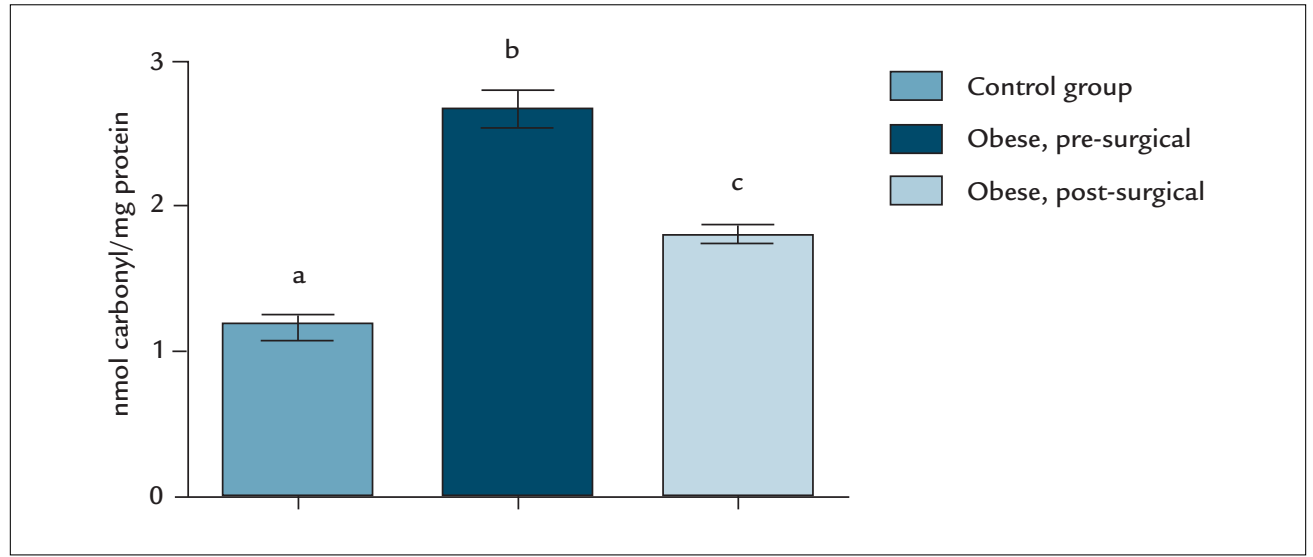

FIGURE 2 Carbonylated protein levels in the plasma of non-obese women $(\mathrm{n}=16)$ and of obese women before and after the bariatric surgery $(n=16)$. Different letters indicate significant differences between the studied groups, considering $p<0.05$.

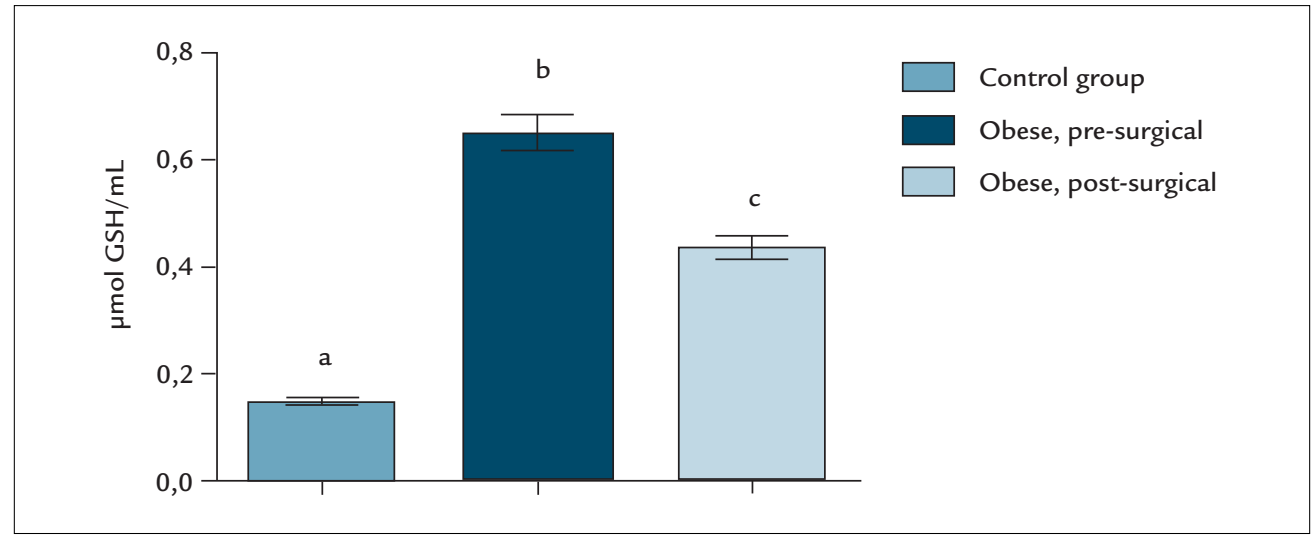

FIGURE 3 Reduced glutathione levels in the plasma of non-obese women $(n=16)$ and of obese women before and after the bariatric surgery $(n=16)$. Different letters indicate significant differences between the studied groups, considering $p<0.05$.

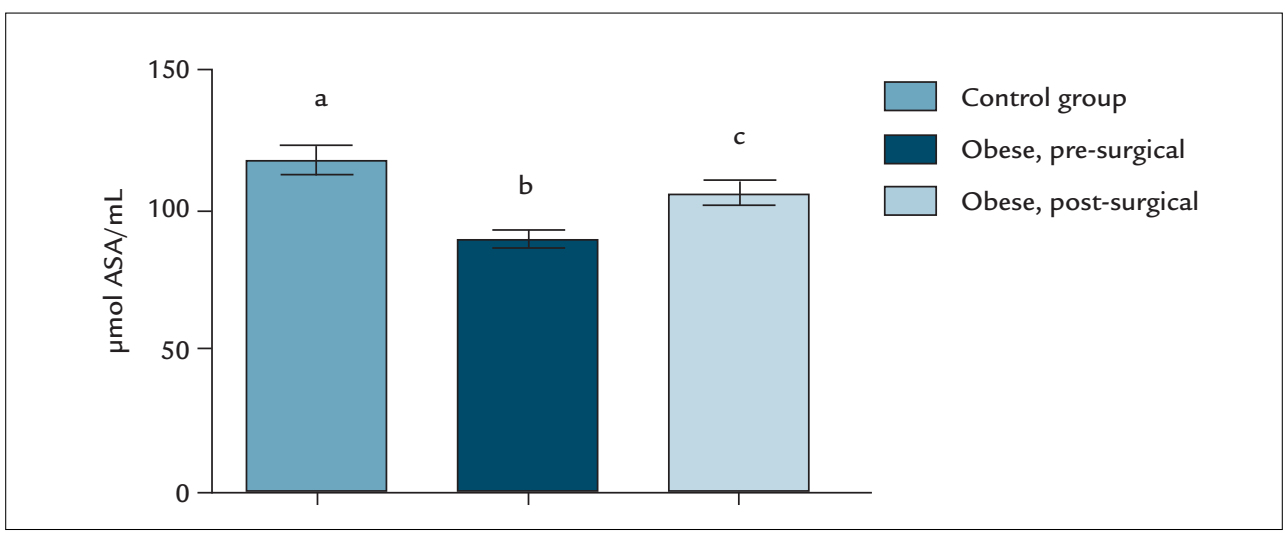

FIGURE 4 Ascorbic acid levels in the plasma of non-obese women $(n=16)$ and of obese women before and after the bariatric surgery ( $n=16$ ). Different letters indicate significant differences between the studied groups, considering $\mathrm{p}<0.05$. 
production. ${ }^{24}$ Furthermore, excess of body fat also affects the mitochondrial metabolism and promotes hyperleptinemia, thus favoring the occurrence of oxidative stress. ${ }^{8-10}$

The formation of lipid peroxidation (LPO) products is one of the consequences from oxidative stress. It may lead to membrane permeability, fluidity and integrity changes, which may eventually result in severe cytotoxicity. ${ }^{10,25}$ The obese patients in our study showed high TBARS levels before bariatric surgery compared to the control group. This suggests that the patients were predisposed to develop many diseases, as well as to face accelerated aging, because the cytotoxicity caused by lipid oxidation favors uncontrolled cell growth and/or cell death. ${ }^{26}$ However, the risk appeared to decline after bariatric surgery, since LPO in the post-surgical obese group was lower than in the pre-surgical obese group. This result may be explained by the decline in body weight presented by the patients since, according to Yesilbursa, ${ }^{27}$ weight loss is accompanied by reduced ROS production and decreased MDA levels. These findings corroborate the study by Valezi et al. ${ }^{28}$ who assessed oxidative stress indicators in obese patients before and after Roux-en-Y gastric bypass. They found significant LPO increase among pre-surgical obese patients compared to the control group.

It is also worth highlighting that the TBARS decrease in the post-surgical women did not achieve the LPO levels found in the control group, as shown in Figure 1. This finding may be related to the short post-surgical period when the samples were taken and it leads to the following hypothesis: if the current research had been carried out during a longer period of time, the LPO of the patients would have achieved the TBARS levels of the non-obese women.

Similar to the lipids, the proteins are also among the main targets of oxidizing agents under oxidative stress conditions, because of the high affinity of ROS for these biomolecules and their abundance in the biological systems. ${ }^{29} \mathrm{CPs}$ are quickly formed and widely used as protein oxidative damage markers. ${ }^{24,30}$

According to Uzun et al., ${ }^{31}$ the excess of nutrients consumed by obese patients appears to contribute to ROS overproduction and, consequently, to oxidative stress occurrence. This explains the high CP levels in the pre-surgical obese group assessed in the current study, as well as the reduced protein damages after the surgery, since the patients had already shown weight loss by then. These results corroborate a similar study conducted by Sledzinski et al., ${ }^{32}$ who found CP levels in obese individuals approximately to be $50 \%$ higher than those of the non-obese group, and $\mathrm{CP}$ levels to be similar to those of the control group six months after gastric surgery.
GSH is the main endogenous antioxidant compound, since its intracellular role comprises the detoxification of xenobiotics and ROS neutralization. ${ }^{33}$ The pre-surgical obese women in our study showed high GSH levels compared to the control group and to the post-surgical obese group. According to Brown et al., ${ }^{34}$ this can be explained by the possible influence of different degrees of obesity on the antioxidant levels. The greater the obesity, the greater the requirement for antioxidant enzymes to combat the damages caused by reactive species. Therefore, antioxidant enzymes are depleted in obesity and substrates such as GSH increase. These results corroborate the findings by Boesing et al., ${ }^{35}$ who also found decreased GSH levels in obese patients after bariatric surgery.

The physicians in the current study have prescribed the use of ASA in the post-operative period in order to improve the patients' antioxidant capacity. This may have contributed to the lower levels of GSH found in the obese group. It is known that ASA is the most versatile and effective water-soluble dietary antioxidant, because it can donate its electrons to be sequestered by a variety of oxidizing species and easily returns to its reduced state through ubiquitous electron donors such as GSH. ${ }^{36}$

The obese women included in our study showed reduced ASA levels compared to the control and post-surgery groups. This may be linked to the inadequate intake of this micronutrient prior to the surgical procedure. According to Vincent and Taylor, ${ }^{37}$ obese individuals usually consume less fruits and vegetables, which are important sources of dietary antioxidants such as ASA. This result may be confirmed by Boesing et al. and Kisakol et al. ${ }^{35,38}$ who found an inverse correlation between BMI and ASA concentrations.

Ascorbic acid levels in the post-surgical obese group were lower than those of the control group. This shows that the vitamin, which derives from the patients' antioxidant diet after surgery, was used to neutralize ROS generated by the remaining excess of body mass, as well as by the invasive bariatric surgery process.

The results of our study corroborate the findings by Kisakol et al., ${ }^{38}$ Uzun et al., ${ }^{31}$ Cabrera et al. ${ }^{39}$ and Ríspoli et al. ${ }^{40}$ who showed the impact of bariatric surgery on the reduction of oxidative stress in obese patients through LPO reduction, as well as through increased GSH levels and catalase activity, which also acts in the endogenous antioxidant system of the glutathione peroxidase.

\section{Conclusion}

Given the change in the levels of the oxidative stress markers analyzed after bariatric surgery, it is possible to affirm that the body mass influences ROS production. 
Moreover, bariatric surgery combined with weight loss and vitamin supplementation decreased cellular oxidation and, therefore, reduced tissue damage in our population of obese women.

The results found in our study emphasize the importance of measuring oxidative stress markers, since they may help improving the quality of life of morbidly obese patients.

\section{Resumo}

Obesidade, cirurgia bariátrica e estresse oxidativo

Introdução: $\mathrm{Na}$ obesidade, verifica-se um acúmulo de tecido adiposo, o que favorece a ocorrência de estresse oxidativo. A fim de diminuir a produção das espécies reativas que levam a danos teciduais, buscam-se alternativas que contribuam para a redução do peso corporal. Este estudo avaliou se os marcadores oxidantes e antioxidantes de obesas antes e após cirurgia bariátrica reduziram o dano oxidativo. Método: Foram avaliadas 16 mulheres obesas mórbidas cinco dias antes e 180 dias após o procedimento cirúrgico. O grupo controle constituiu-se de 16 mulheres não obesas. Os níveis das substâncias reativas ao ácido tiobarbitúrico, das proteínas carboniladas, da glutationa reduzida e do ácido ascórbico foram avaliados no plasma dessas pacientes.

Resultados: Os níveis de lipoperoxidação e da carbonilação de proteínas nas obesas pré-cirúrgicas eram mais elevados quando comparados ao controle e às obesas pós-cirúrgicas; os níveis de glutationa reduzida eram maiores nas obesas pré-cirúrgicas em comparação ao controle e diminuíram após a cirurgia; os níveis de ácido ascórbico eram menores nas obesas pré-cirúrgicas em relação ao controle e às obesas pós-cirúrgicas.

Conclusão: Observou-se que a massa corporal influenciou na produção das espécies reativas. A cirurgia bariátrica, somada à perda de peso e à suplementação vitamínica, diminui a oxidação celular e, com isso, reduz os danos teciduais.

Palavras-chave: tecido adiposo, espécies reativas, perda de peso, obesidade mórbida, cirurgia bariátrica, estresse oxidativo.

\section{RefEREnCES}

1. Santos TD, Burgos MGA, Lemos MCC, Cabral PC. Clinical and nutritional aspects in obese women during the first year after roux-en-y gastric bypass Arq Bras Cir Dig. 2015; 28(Suppl 1):56-60.

2. Ministério da Saúde. VIGITEL Brasil 2013 [cited 2016 Feb 6]. Available from: https://biavati.files.wordpress.com/2014/05/vigitel-2013.pdf.
3. Souza MDG, Vilar L, Andrade CB, Albuquerque RO, Cordeiro LHO, Campos $\mathrm{JM}$, et al. Prevalência de obesidade e síndrome metabólica em frequentadores de um parque. Arq Bras Cir Dig. 2015; 28(Suppl 1):31-5.

4. WHO - World Health Organization. Obesity: preventing and managing the global epidemic. Report of a World Health Organization Consultation. Geneva: World Health Organization; 2000. p. 252. [WHO Obesity Technical Report Series].

5. França BK, Alves MRM, Souto FMS, Tiziane L, Boaventura RF, Guimarães A, et al. Peroxidação lipídica e obesidade: métodos para aferição do estresse oxidativo em obesos. J Port Gastrenterol. 2013; 20(5):199-206.

6. Serra D, Mera P, Malandrino MI, Mir JF, Herrero L. Mitochondrial fatty acid oxidation in obesity. Antioxid Redox Signal. 2013; 19(3):269-84.

7. Surmi BK, Hasty AH. The role of chemokines in recruitment of immune cells to the artery wall and adipose tissue. Vascul Pharmacol. 2010; 52(1-2):27-36.

8. Tilg H, Moschen AR. Adipocytokines: mediators linking adipose tissue, inflammation and immunity. Nat Rev Immunol. 2006; 6(10):772-83.

9. Ceci R, Sabatini S, Duranti G, Savini I, Avigliano L, Rossi A. Acute, but not chronic, leptin treatment induces acyl-CoA oxidase in C2C12 myotubes. Eur J Nutr. 2007; 46(6):364-8

10. Bełtowski J. Leptin and the regulation of endothelial function in physiological and pathological conditions. Clin Exp Pharmacol Physiol. 2012;39(2):168-78

11. Moyer VA; U.S. Preventive Services Task Force. Screening for and managemen of obesity in adults: U.S. Preventive Services Task Force recommendation statement. Ann Intern Med. 2012; 157(5):373-8.

12. Sanivi I, Catani MV, Evangelista D, Gasperi V, Avigliano L. Obesity-associated oxidative stress: strategies finalized to improve redox state. Int J Mol Sci 2013; 14(5):10497-538.

13. Ferraz EM, Arruda PCL, Barcelar TS, Ferraz AAB, Albuquerque AC, Leão CS. Tratamento cirúrgico da obesidade mórbida. Rev Col Bras Cir. 2003; 30(2):98-105.

14. Santry HP, Gillen DL, Lauderdale DS. Trends in bariatric surgical procedures. JAMA. 2005; 294(15):1909-17

15. Bordalo LA, Teixeira TFS, Bressan J, Mourão DM. Cirurgia bariátrica: como e por que suplementar. Rev Assoc Med Bras. 2011; 57(1):113-20.

16. Nicoletti CF, Lima TP, Donadelli SP, Salgado W Jr, Marchini JS, Nonino CB. New look at nutritional care for obese patient candidates for bariatric surgery Surg Obes Relat Dis. 2013; 9(4):520-5.

17. Brasil. Resolução de Diretoria Colegiada - RDC n. 269 de 22 de setembro de 2005. Aprova o regulamento técnico sobre a ingestão diária recomendada (IDR) de proteína, vitaminas e minerais. ANVISA; 2005.

18. Westling A, Gustavsson S. Laparoscopic vs open Roux-en-Y gastric bypass: a prospective, randomized trial. Obes Surg. 2001; 11(3):284-92.

19. Zeve JLM, Novais PO, Oliveira Júnior N. Técnicas em cirurgia bariátrica: uma revisão da literatura. Ciência \& Saúde. 2012; 5(2):132-40.

20. Jentzsch AM, Bachmann H, Fürst P, Biesalski HK. Improved analysis of malondialdehyde in human body fluids. Free Radical Bio Med. 1996; 20(2):251-6

21. Levine RL, Garland D, Oliver CN, Amici A, Climent I, Lenz AG, et al. Determination of carbonyl content in oxidatively modified proteins. Methods Enzymol. 1990; 186:464-78.

22. Elmman GL. Tissue sulfhydryl groups. Arch Biochem Biophys.1959; 82(1):70-7

23. Roe JH. Chemical determination of ascorbic, dehydro ascorbic and diketogulonic acids. Meth Biochemical.1954; 1:115-39.

24. Murussi C, Horn RC, Santi A, Clasen BE, Reis G, Souza D, et al. Changes in oxidative markers, endogenous antioxidants and activity of the enzyme acetylcholinesterase in farmers exposed to agricultural pesticides - a pilot study. Ciênc Rural. 2014; 44(7):1186-93.

25. Circu ML, Aw TY. Reactive oxygen species, cellular redox systems, and apoptosis. Free Radic Biol Med. 2010; 48(6):749-62.

26. Yadav UC, Ramana KV. Regulation of NF-кB-induced inflammatory signaling by lipid peroxidation-derived aldehydes. Oxid Med Cell Longevity. 2013; 2013:690545.

27. Yesilbursa D, Serdar Z, Serdar A, Sarac M, Coskun S, Jale C. Lipid peroxides in obese patients and effects of weight loss with orlistat on lipid peroxides levels. Int J Obes (Lond). 2005; 29(1):142-5.

28. Valezi AC, Cabrera EJ, Delfino DA, Barbosa DS, Mali Junior J, Menezes MA [Roux-en-Y gastric bypass and inflammatory activity of the adipose tissue]. Rev Col Bras Cir. 2011; 38(3):161-6. 
29. Negre-Salvayre A, Auge N, Ayala V, Basaga H, Boada J, Brenke R, et al Pathological aspects of lipid peroxidation. Free Radic Res. 2010; 44(10):1125-71.

30. Dalle-Donne I, Rossi R, Giustarini D, Milzani A, Colombo R. Protein carbonyl groups as biomarkers of oxidative stress. Clin Chim Acta. 2003; 329(1-2):23-38.

31. Uzun H, Zengin K, Taskin M, Aydin S, Simsek G, Dariyerli N. Changes in leptin, plasminogen activator factor and oxidative stress in morbidly obese patients following open and laparoscopic Swedish adjustable gastric banding. Obes Surg. 2004; 14(5):659-65.

32. Sledzinski T, Goyke E, Smolenski RT, Sledzinski Z, Swoierczynski J. Decrease in serum protein carbonyl groups concentration and maintained hyperhomocysteinemia in patients undergoing bariatric surgery. Obes Surg. 2009; 19(3):321-6.

33. Höhn A, König J, Grune T. Protein oxidation in aging and the removal of oxidized proteins. J Proteomics. 2013; 92:132-59.

34. Brown LA, Kerr CJ, Whiting P, Finer N, McEneny J, Ashton T. Oxidant stress in healthy normal-weight, overweight, and obese individuals. Obesity (Silver Spring). 2009; 17(3):460-6.
35. Boesing F, Moreira EA, Wilhelm-Filho D, Vigil SV, Parizotto EB, Inácio DB, et al. Roux-en-Y bypass gastroplasty: markers of oxidative stress 6 months after surgery. Obes Surg. 2010; 20(9):1236-44.

36. Vasconcelos SML, Goulart MOF, Moura JBF, Manfredini V, Benfato MS, Kubota LT. Espécies reativas de oxigênio e de nitrogênio, antioxidantes e marcadores de dano oxidativo em sangue humano: principais métodos analíticos para sua determinação. Quim Nova. 2007; 30(5):1323-38.

37. Vincent HK, Taylor AG. Biomarkers and potential mechanisms of obesityinduced oxidant stress in humans. Int J Obes (Lond). 2006; 30(3):400-18.

38. Kisakol G, Guney E, Bayraktar F, Yilmaz C, Kabalak T, Ozmen D. Effect of surgical weight loss on free radical and antioxidant balance: a preliminary report. Obes Surg. 2002; 12(6):795-800.

39. Cabrera EJ, Valezi AC, Delfino VD, Lavado EL, Barbosa DS. Reduction in plasma levels of inflammatory and oxidative stress indicators after Rouxen-Y gastric bypass. Obes Surg. 2010;20(1):42-9.

40. Ríspoli LT, Tarragón AV, Prado AV, Torno GS, Mahmoud AI, Esteban BM, et al. Relación del estrés oxidativo y pérdida de peso obtenida en pacientes obesos mórbidos mediante cirugía bariátrica conla técnica del cruce duodenal. Nutr Hosp. 2013; 28(4):1085-92. 